\title{
Results of Comparison of Survey of Pasture and Recreation and Tourism Places with Intake for More Than 10 Years
}

\section{(On the example of Gorkhi-Terelj National Park)}

\author{
B. Lhamsuren ${ }^{*}$,, B. Odgerel1², Kh. Bayarmaa ${ }^{3}$., Sh. Purevsuren ${ }^{4}$ \\ ${ }^{1}$ School of Agroecology Department of Mongolian University of Life Science \\ ${ }^{2}$ School of Agroecology Department of Mongolian University of Life Science \\ ${ }^{3}$ School of Agroecology Department of Mongolian University of Life Science \\ ${ }^{4}$ School of Agroecology Department of Mongolian University of Life Science
}

DOI: 10.29322/IJSRP.10.10.2020.p10664

http://dx.doi.org/10.29322/IJSRP.10.10.2020.p10664

\begin{abstract}
The study compared and compared the changes and degradation of soil properties depending on the conditions of use of the protected area by the Pastureland, Recreation and Tourism Department. We made an incision in the Gorkhi-Terelj National Park area for pasture and recreational and tourism purposes, made morphological records, determined the physical and chemical properties of the soil, and selected the soil characteristics of the protected area for more than 10 years. compared with quality. The soil type studied is dark brown mountain soil.

According to the results of physical and chemical analysis of the soil, the humus content of 0-8 cm of pasture and recreational and tourist soil decreased by 2.6-2.7\% from the fenced area selected for control, and became a light clay in terms of mechanical composition, which is the main indicator of soil physical properties. , sand content increased by $5.6 \%$ and physical clay content decreased by $2.6 \%$. In addition, the content of soil nutrients such as mobile phosphorus and exchangeable potassium is lower than in the fenced area [8]. In terms of plant species composition, pastures and recreational areas decreased by 65.8\%.

Based on the above results, there is reason to believe that the soil of Gorkhi-Terelj National Park has been affected by overgrazing and degradation..
\end{abstract}

Key words: Soil degradation, soil physical and chemical properties, mechanical composition, pasture, recreation and tourism areas

\section{Introduction}

Soil cover is deteriorating due to environmental and climate change, urbanization, recreation, tourism, and livestock growth, which is increasing the negative impact on ecosystems.

In Mongolia's protected areas, soil degradation is severe, vegetation is depleted, and the environment is adversely affected. In recent years, this situation has become more pronounced in the Gorkhi-Terelj National Park, one of the most popular places for vacationers and tourists.

The main purpose of our research is to study the changes and degradation of soil properties depending on the conditions of use of protected areas. To achieve this goal, the following objectives have been set. These include:

1. To study and identify changes in the condition and characteristics of stabilized soils in areas with high impact on pastures, recreation and tourism in comparison with the soils of fenced areas selected for more than 10 years.

2. Compare the vegetation of the area with the fenced area during the same period

Materials and methods

Research area: 42782.9 hectares of Gorkhi-Terelj National Park, 60-70 km from Ulaanbaatar, adjacent to Khan-Khentii Strictly Protected Area.

The main method of soil field research is to make an incision in the soil and make a morphological record, and we made the incision in the soil according to a common methodology. Soil morphology records the soil color of each layer, layer thickness, 
structure, density, moisture, carbonate, petrification, plant root distribution, location, and layer shift. The ingestion of soil from the pasture will depend upon the duration of the visit and to an extent on the age of the individual (Environmental Protection Agency, 1996). Van Wijnen et al. (1990) report that soil intake by children on a camp site ranges from 30 to $200 \mathrm{mg}$ per $24 \mathrm{~h}$, while Haas (2000) estimates ingestion per working day by agricultural workers to have a median value of approximately 10 mg. When performing chemical risk assessments, the United States Environmental Protection Agency assumes a daily soil ingestion rate of $200 \mathrm{mg}$ for each 24-h period (EPA, 1996). In this study, two scenarios with different amounts of soil ingested by humans are considered. The first involves a 24-h stay including an overnight camp and uses the soil ingestion data of van Wijnen et al. (1990) and the second involves a day visit ( $8 \mathrm{~h}$ ) and uses the data supplied by Haas (2000). The physical and chemical properties of the soil were performed by the following methodology. These include:

- Physical properties of the soil: The mechanical composition of the soil was determined by the Kaczynski method, the volume of the soil by the cylinder, the density of the solid part of the soil by the pycnometer method and the soil porosity by the calculation method. The pycnometer method is used for determination of specific gravity of soil particles of both fine grained and coarse grained soils. The determinination of specific gravity of soil will help in the calculation of void ratio, degree of saturation and other different soil properties Soil chemical properties: Soil reaction environment was determined by Potentiometric method, Soil humus was determined by Turing method, Mobile phosphorus and Potassium exchange was determined by Machiginy method.

- The following methods of statistical processing of field and laboratory research materials were widely used. Mathematical modeling methods, numerical data summarization, statistical generalization, test, interval and SPSS statistics 22 software were developed.

\section{Results and Discussion}

We determined the physical and chemical properties of the soils of pastureland and recreation and tourism areas and the composition of plant species, and compared them with the soils of the fenced area selected as the main results (Table 1-4).

\begin{tabular}{|cccc|}
\hline Study area & Sampling depth $(\mathrm{cm})$ & Soil density $(\mathrm{g} / \mathrm{cm} 3)$ & Porosity $(\%)$ \\
\hline Intake protected & $0-8$ & $1.08 \pm 0.08$ & $59 \pm 54.1$ \\
$($ Control $)$ & $10-16$ & $1.15 \pm 0.04$ & $57.2 \pm 53.9$ \\
& & & \\
Pastureland & $0-8$ & $1.24 \pm 0.06$ & $53.9 \pm 52.9$ \\
recreation and & $10-16$ & $1.32 \pm 0.03$ & $53.9 \pm 52.9$ \\
tourism place & & & \\
\hline
\end{tabular}

Table 1. Comparison of physical properties of soil in the study area

According to the above results, $1.24 \mathrm{~g} / \mathrm{cm} 3$ or $0.16 \mathrm{~g} / \mathrm{cm} 3$ in the $0-8 \mathrm{~cm}$ layer of compacted dark brown mountain soil and 0.16 $\mathrm{g} / \mathrm{cm} 3$ in the indoor area and $1.32 \mathrm{~g} / \mathrm{cm} 3$ or $0.17 \mathrm{~g}$ in the $10-16 \mathrm{~cm}$ depth. $/ \mathrm{cm} 3$. In addition, the total porosity of $0-8 \mathrm{~cm}$ of soil in pasture, recreation and tourism areas was 5.1\% lower than the same period, and 5.2\% less in 10-16 cm. This shows that the soils of pastures and recreational areas have become denser due to human, livestock and technical degradation.

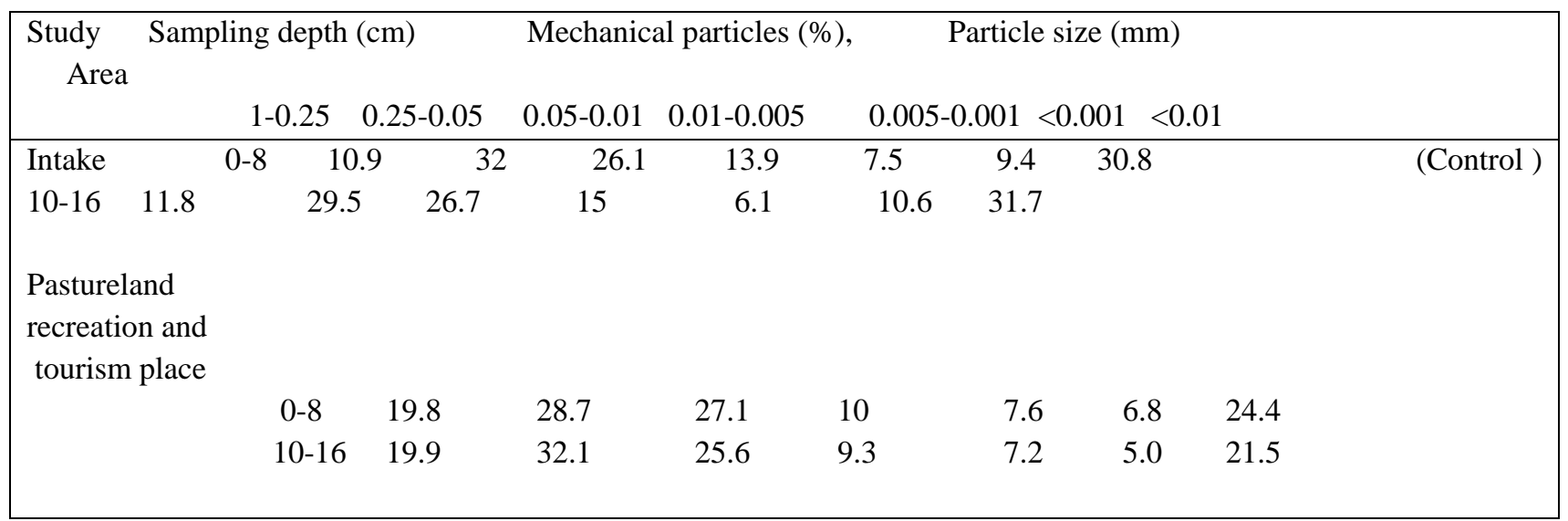

Table 2. Mechanical composition of soil in the study area 
As for the mechanical composition of the soil, N. A. According to Kaczynski's classification, the content of physical clay $(<0.01$ $\mathrm{mm}$ ) in the fenced area decreased by $30.8-31.8 \%$ or medium loam in the upper layers of the soil, and by $6.4-10.2 \%$ in the upper layers of pasture and recreation areas. This is a sign that the mechanical composition of the soil has deteriorated.

\begin{tabular}{|cccccccc|}
\hline $\begin{array}{l}\text { Study } \\
\text { Area }\end{array}$ Sampling \\
depth $(\mathrm{cm})$
\end{tabular}

Table 3. Chemical properties of soil in the study area

From the above results, there is no significant difference in the soil reaction environment in the fenced area and the pasture, recreation and tourism area is slightly acidic, but the salt content is $0.033-0.037 \%$ higher than the fenced area in the $0-8$ $\mathrm{cm}$ layer of the pasture, recreation and tourism area. is. This indicates that the soils of pastures and recreational and tourism areas are prone to salinization.

Fertility indicators, such as mobile phosphorus and potassium, also vary in fenced and pasture, recreational and tourism areas. The mobile phosphorus content is $0.3 \mathrm{mg}$ lower and the potassium content is $11.1 \mathrm{mg}$ lower than the fenced area in the $0-8$ $\mathrm{cm}$ layer of pasture, recreation and tourism soil, which indicates a decrease in the content of these substances in the pasture and recreation area. The concentration of E. coli $\mathrm{O} 157$ in faeces is the most important parameter and has a positive correlation. This demonstrates that as the concentration increases, then the probability of infection also increases. The type of visit also shows an important positive correlation. For longer visits (24-h camp), the probability of infection increases due to increased ingestion of soil quantity and hence increase in numbers of pathogen ingested. The host susceptibility (the probability of infection by a single organism) defined in the dose - response model is an important parameter and is also positively correlated. This result is expected because the greater the susceptibility of the individual then the greater the probability of infection. The other positively correlated variables are less important and it is worth noting that this includes duration of time the animals are on the field. It can be seen from Fig. 2a that the build-up of pathogen on the pasture does not increase at a significant rate once the cattle have been on the field for more than $8-9$ days and hence the low correlation result was expected.

In order to determine whether there is a change in the vegetation cover of the surveyed area, we compared the plant species with a total of 6 iterations of geobatonic records in fenced and pasture, recreation and tourism areas (Table 4).

\begin{tabular}{|c|c|c|c|c|c|}
\hline \multirow[t]{2}{*}{ № } & \multirow[t]{2}{*}{ Plants } & Intak & \multicolumn{3}{|c|}{$\begin{array}{l}\text { Pastureland } \\
\text { recreation and } \\
\text { tourism place }\end{array}$} \\
\hline & & Type & Item & Type & Item \\
\hline 1 & Asteraceae & 3 & 6 & 2 & 3 \\
\hline 2 & Crassulaceae DC & - & - & - & - \\
\hline 3 & Rosaceae & 1 & 3 & 1 & 1 \\
\hline
\end{tabular}




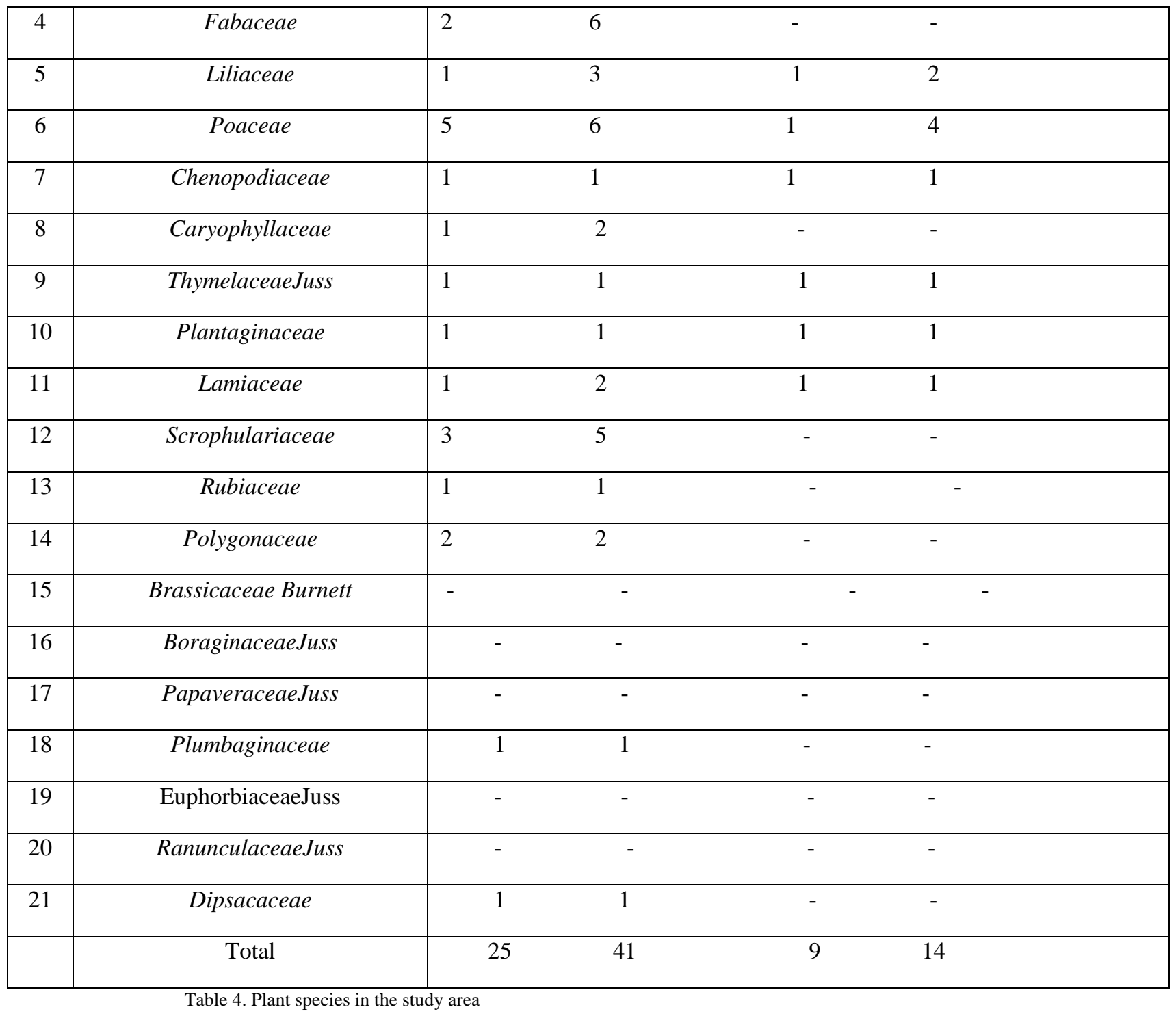

According to the above results, 25 species and 41 species of plants were registered in the area protected for more than 10 years, and 9 species and 14 species of plants were registered in the areas with pastures, recreation and tourism $[8,10]$.

Based on the results of the above study, we compared the changes in soil and vegetation in the area with the following key indicators (Table 5).

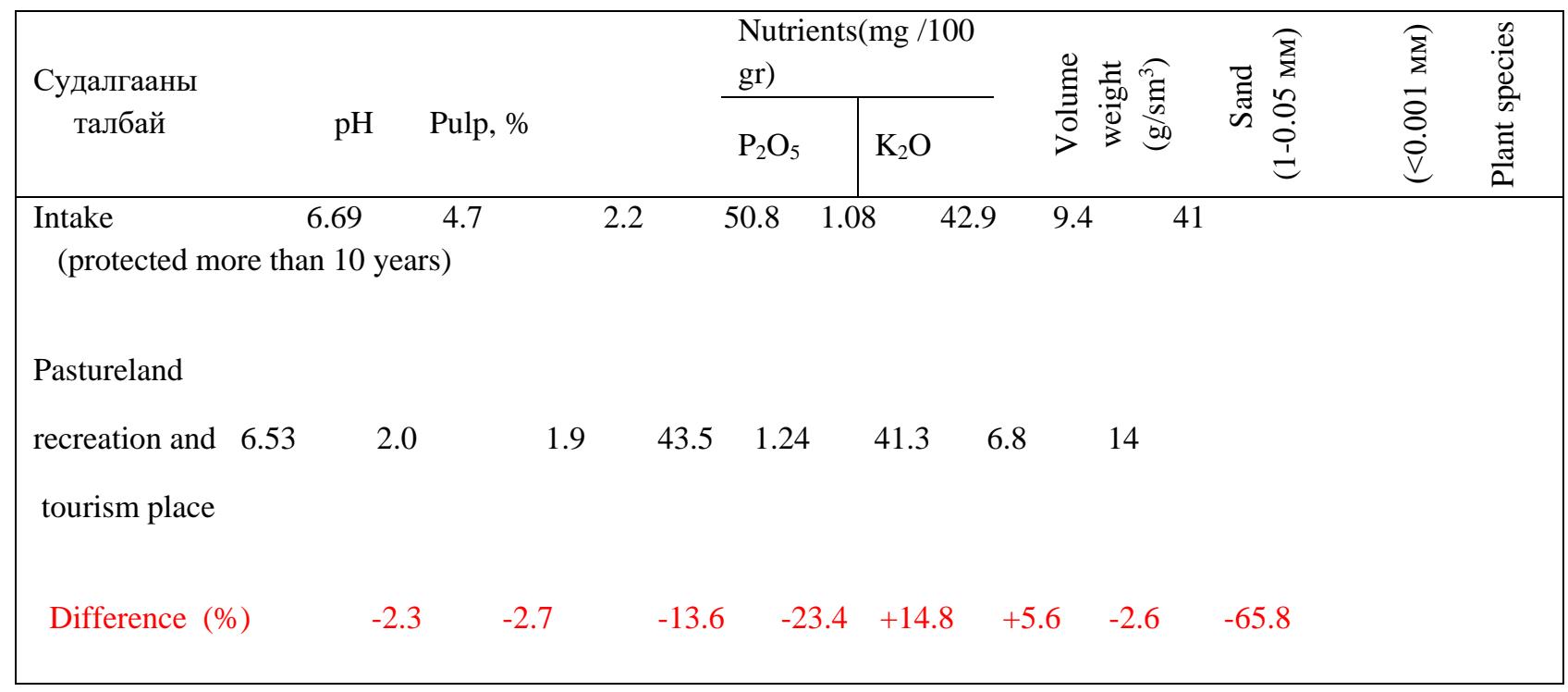


Table 5. Changes in soil cover characteristics of pastures and recreational areas $(0-8 \mathrm{~cm})$

As a result, the humus content in the $0-8 \mathrm{~cm}$ layer of pasture and recreation soil decreased by $2.7 \%$ compared to the fenced area, and the content of nutrients such as phosphorus and potassium decreased by 13.6-23.4\%.

In terms of soil physical properties, the sand content of pastures increased by $14.8 \%$, the sand content increased by $5.6 \%$, the clay content decreased by $2.6 \%$ and the plant species composition decreased by $65.8 \%$ compared to the fenced areas of pastures and recreation and tourism areas. This suggests that the soil properties of pastures and recreational areas are being severely degraded and eroded.

\section{Conclusion}

1. The sand content increased by $5.6 \%$, the physical clay content increased by $2.6 \%$, and the humus content, which is the main indicator of fertility, increased by $2.7 \%$. The content of iron, phosphorus and potassium decreased by $13.6-23.4 \%$, respectively.

2. According to the results of the vegetation survey, the vegetation of pastures, recreation and tourism areas decreased by 16 species and 27 species compared to the fenced areas. This suggests that the soil in the area has deteriorated significantly.

\section{Discussion}

The results of the study of soil degradation in the Gorkhi-Terelj National Park are compared with the work of other researchers and the results of the study. These include:

D. Dorjgotov $(1986,2003)$ A detailed soil study was conducted in Mongolia to determine each soil type. According to his research, the humus content in the $0-10 \mathrm{~cm}$ layer of dark brown mountain soil is 3.4-5.6\%, and the reaction medium is neutral to $\mathrm{pH}$ 6.9-7.0. In terms of particle composition, sand and light loam $(<0.01 \mathrm{~mm}$ fraction $16-22 \%,<0.001 \mathrm{~mm}$ fraction $2-10 \%)$ have mechanical components. In our study, the humus content was $2-4.7 \%$ in the $0-8 \mathrm{~cm}$ layer of dark brown mountain soil, the reaction medium was weakly acidic $\mathrm{pH} 6.5-6.6$, and the light clay loam in terms of particle composition $(<0.01 \mathrm{~mm}$ percentage was $24.4-30.8 \%,<0.001 \mathrm{~mm}-6.8-9.4 \%$ ) of the mechanical components.

D. According to Avaadorj's researchers (1990-2000), the humus content of dark brown mountain soil is 2.07-3.24\%, while in our study it is $2-4.7 \%$.

\section{References}

[1] Avaadorj D., Odgerel B., (2014) Soil science. Ulaanbaatar. x 115-165

[2] Avaadorj. D., Odgerel B., Battulga O., (2012) Soil science practice and laboratory work. Ulaanbaatar. x 78-84

[3] Грубов В. И. (1982) Identification of Mongolian tubular plants. Ulaanbaatar. x 325-432

[4] GTBP., (2015) Gorkhi-Terelj National Park Management Plan. (2015-2020). Ulaanbaatar. x 18-48

[5] Odgerel B., Buyanbaatar A. (2010) Soil science. Ulaanbaatar. x 145-210

[6] Oyungerel B., others. (2012) Resource and capacity survey of tourism zones in state special protected areas. Ulaanbaatar. x 5$10,31-33,46-52$

[7] Purevsuren Sh. (1991) Changes in the properties of chestnut soils in the agrocoenosis. Author's abstract.

[8] Lkhamsuren B., Purevsuren Sh., Odgerel B., (2016) Comparative results of agrochemical properties of pasture forest steppe zones with protected fields (for example, Gorkhi-Terelj National Reserve). Eurasian Union of scientists.M., Pp 96-98

[9] Lkhamsuren B., Purevsuren Sh., Odgerel B., (2017) Results of soil degradation studies in the National Park (on the example of the SPA). Doctoral dissertation. Ulaanbaatar. x 64-66, 71-72Burghardt W (1994) Soils in urban and industrial environments. J Plant Nutr Soil Sci 157:205-214

Beylich A., Oberholzer HR., Schrader S., Hoper H., Wilke BM. (2010) Evaluation of soil compaction effect on soil biota and soil biological processes in soils. Soil Till Res 109:133-143

Maas S., Scheifler R., Benslama M., Crini N, Lucot E., Brahmia Z., Benyacoub S., Giraudoux P. (2010) Spatial distribution of heavy metal concentration in urban, suburban and agricultural soils in a Mediterranean city of Algeria. Environ Pollut 158:22942301 
Jim CY. (1998) Physical and chemical properties of a Hong Kong roadside soil in relation to urban tree growth. Urban Ecosyst 2: 171-181

Lipies J., Wojciga A., Horn R. (2009) Hydraulic properties of soil aggregates as influenced by compaction. Soil Till Res 103:170177

Yang JL., Zhang GL., Yuan DG. 2008. Characteristics of water infiltration in urban soils of Nanjing City. Chinese J Appl Ecol 19 (2):363-368 